\title{
Psychosocial X Biomedical Paradigm: Where is the Social Representation Anchored in Psychic Suffering?
}

Patricia Fonseca Sousa ${ }^{1, *}$

Orcid.org/0000-0003-1885-2626

Silvana Carneiro Maciel $^{1}$

Orcid.org/0000-0003-1489-1126

Katruccy Tenório Medeiros ${ }^{1}$

Orcid.org/0000-0001-7741-2044

${ }^{1}$ Universidade Federal da Paraíba, João Pessoa, PB, Brasil

\begin{abstract}
This study aims to determine the social representation of mental health professionals, university students from the health area, and secondary school students with regard to the crazy person and the mentally ill person, regarding the paradigms of mental health care. The study sample was composed of 150 participants, with 50 in each social group. For data collection, the free word association technique (TALP) was used, with the prompts "crazy person" and "mentally ill person". The data were analyzed using the Tri-Deux-Mots software, through correspondence factor analysis. The secondary school students and university students presented representations of the crazy person and the mentally ill person anchored in the biomedical paradigm, which emphasizes medicalization and hospitalization with regard to mental health care. The professionals, on the other hand, presented representations anchored in the psychosocial paradigm, which guides the ideas of the Psychiatric Reform. It is recognized that although mental health care in Brazil is based on the principles of the Reform, there is still a negative view of the mentally ill person/crazy person on the part of society anchored in the biomedical paradigm, which reinforces the exclusion and maintenance of the social stigma that these individuals face.
\end{abstract}

Keywords: Crazy Person, Mentally Ill Person, Social Representation, Biomedical Paradigm, Psychosocial Paradigm.

\section{Paradigma Biomédico X Psicossocial: Onde são Ancoradas as Representações Sociais Acerca do Sofrimento Psíquico?}

\section{Resumo}

Este estudo tem como objetivo conhecer as representações sociais de profissionais da saúde mental, universitários da área da saúde e estudantes do ensino médio acerca do louco e do doente mental, relacionando-as aos paradigmas de atenção à saúde mental. A amostra dessa pesquisa foi formada por

Mailing address: Universidade Federal da Paraíba, Campus universitário, João Pessoa, PB, Brazil 58059-900. E-mail: patriciasousa20@yahoo.com.br, silcamaciel@gmail.com and katruccy_22@yahoo.com.br Support: Coordenação de Aperfeiçoamento de Pessoal de Nível Superior (CAPES) 
150 participantes, sendo 50 de cada grupo social. Para a coleta de dados, foi usada a TALP (Técnica de Associação Livre de Palavras), com os estímulos louco e doente mental. Os dados foram analisados no programa Tri-Deux-Mots, por meio da Análise Fatorial de Correspondência. Os estudantes do ensino médio e os universitários apresentaram representações do louco e do doente mental ancoradas no paradigma biomédico, o qual enfatiza a medicalização e a hospitalização na assistência à saúde mental; já os profissionais apresentaram representações ancoradas no paradigma psicossocial, o qual norteia as ideias da Reforma Psiquiátrica. Percebe-se que apesar de a assistência em saúde mental no Brasil ser pautada nos preceitos da reforma, ainda há na sociedade uma visão negativa do doente mental/louco ancorada no paradigma biomédico, a qual reforça a exclusão e manutenção do estigma social frente a esses sujeitos.

Palavras-chave: Louco, doente mental, representação social, paradigma biomédico, paradigma psicossocial.

\section{Paradigma Biomédico X Psicosocial: ¿Dónde están Ancladas las Representaciones Sociales Acerca del Sufrimiento Psíquico?}

\section{Resumen}

El objetivo fue conocer las representaciones sociales de profesionales de salud mental, estudiantes de la salud y de enseñanza secundaria sobre locos y enfermos mentales, relacionándose los paradigmas de la atención a la salud mental. Muestra formada por 150 participantes, 50 de cada grupo social. Para recolección de datos, se utilizó la Técnica de Asociación Libre de Palabras, con estímulos locos y enfermos mentales. Datos analizados en el software Tri-Deux-Mots, a través del análisis factorial de correspondencia. Los estudiantes de enseñanza secundaria y los universitarios presentaron representaciones de loco y enfermo mental ancladas en el paradigma biomédico, que hace hincapié a la medicalización y hospitalización en la atención de salud mental; ya los profesionales presentaron representaciones ancladas en el paradigma psicosocial, que guía las ideas de la Reforma Psiquiátrica. Se percibió que a pesar de la atención en salud mental en Brasil se basada en los preceptos de la Reforma, todavía hay en la sociedad visión negativa de enfermos mentales/loco anclada en el paradigma biomédico, lo que refuerza la exclusión y el mantenimiento del estigma social delante de estos sujetos.

Palabras clave: Loco, enfermo mental, representación social, paradigma biomédico, paradigma psicosocial.

Prior to the Psychiatric Reform movement, mental health care was the purview of large asylums, described by Goffman (2008) as a type of total institution, in which a large number of individuals were separated from society, for a considerable period of time, leading a closed and formally administered life. These institutions had the duty of excluding people in psychic suffering from the social environment under the justification of treating them to subsequently return the rehabilitated individuals to social coexistence. However, this discourse had no practical support within the walls of psychiatric hospitals, which operated on the logic of segregation. This produced a loss of identity and reduced individuals to their mental illness - understood as a social or moral deviance - and, thus, to a poor therapeutic prognosis (Emerich, Campos, \& Passos, 2014; Silva, Simpson, \& Dantas, 2014).

The Psychiatric Reform movement, which began in the 1970s, implemented a set of transformations in mental health care to break the hegemony of the asylum model, which segregated and excluded people in psychic suffering. To that end, mental health policies took on a new direction, toward a paradigm shift, seeking to 
overcome the biomedical paradigm and to establish a psychosocial paradigm of mental health care (Fonseca \& Jaeger, 2012).

According to Costa Rosa (2000), under the biomedical paradigm, the psychiatric hospital is the typical place of treatment; the working methods include multidisciplinary resources but do not overcome the fragmentation of tasks and the overvaluation of medical knowledge; there is an emphasis on organic determinations of problems (illness) and drug therapy. Another peculiarity of this model is the exclusion of family members and users from any participation in the treatment process.

In contrast, the psychosocial paradigm, which has developed alongside the Psychiatric Reform, is characterized by the work of a multidisciplinary team and the use of different therapeutic resources, emphasizing the individual's social re-integration, investing in working with the family, the community, and the individual himself, and encouraging the use of extra-hospital resources. This paradigm proposes the promotion of effective and humanized care, a reduction in asylum hospitalizations, and the participation of the family, community, and users as being co-responsible in the person's rehabilitation and in social reintegration. Thus, the psychosocial paradigm is characterized as a guideline of the Reform and assumes the important role of guiding the construction of new mental health practices and services (Acioli Neto \& Amarante, 2013; Costa-Rosa, 2000; Maciel, 2007; Silva et al., 2014).

The Psychiatric Reform is considered an important milestone that has led to wide-reaching changes in mental health care. This policy came about to improve the quality of life of people in psychic suffering, giving their citizenship and freedom back to them and reintroducing them into the family and society as subjects of law. In Brazil, the Reform was institutionalized in 2001, when Law No. 10,216, or the Brazilian Psychiatric Reform Law, was enacted. However, more than a decade after the approval of the National Psychiatric Reform Law, the relationship between society and the person in psychic suffering still appears to be rooted in socio-cultural aspects that were constructed during the asylum period and that are marked by the stereotypes of danger, irrationality, and unpredictability, the idea of confinement, and notions associated with the outdated biomedical paradigm. As a result, people in psychic suffering are also recurrently targets of prejudice, stigmatization, and the most severe forms of social exclusion (Corrigan, Markowitz, Watson, Rowan, \& Kubiak, 2003; Costa, Jorge, Coutinho, Costa, \& Holanda, 2016; Maciel, Barros, Camino, \& Melo, 2011).

It is against this challenging backdrop that the Psychiatric Reform movement gradually seeks to alter conceptions, rebuild rooted representations, and call upon society to reflect and make changes to develop strategies that facilitate respect for the social rights of people in psychic suffering and, in so doing, break away from the culture of exclusion built over time (Martins, Soares, Oliveira, \& Souza, 2011).

On this point, Maciel, Barros, Silva, and Camino (2009) note that for there to be a transformation of this situation, much more than a change to institutional arrangements is needed; it is necessary that the asylum model is overcome both quantitatively and qualitatively; there needs to be a social restructuring based on a logic opposed to this idea, that is, based on the logic of deinstitutionalization and social inclusion.

In this context of change, the community plays an important role because it must be prepared to receive these de-hospitalized people into everyday life. For this reason, it is important to adopt different social segments as objects of study, given that the Reform assigns a key role to the interaction between society and the person in psychic suffering, with the goal of social inclusion. Therefore, this study involves three distinct social groups and aims to understand the social representations of mental health professionals, university students in the health field, and secondary school students with regard to the crazy person and the mentally ill person and relate them to mental health care paradigms.

Note that we chose to use the terms mentally ill person and crazy person because these are also commonly used by people to refer to those who experience psychic suffering. Such 
terms have been used throughout history, from the understanding of the crazy person as associated with something mythical-religious to the appropriation of medical knowledge regarding mental illness (Pessotti, 1994); furthermore, they are still widely used in the vernacular; they would therefore seem to be the most appropriate for ascertaining social representations.

Social representation theory is adopted as a theoretical framework when attempting to understand this complex mental health scenario. This theory is a tool that makes it possible to examine how scientific knowledge is transformed when it becomes the common domain and is appropriated by the population, uniting subjective and objective dimensions and enabling the construction of a social reality. Social representations may be viewed as a way of interpreting and thinking about everyday reality. They are a type of knowledge developed by individuals to establish their positions on situations, events, and objects and are closely related to social practices (Moscovici, 2012).

Camargo (2015) states that it is a theory of contemporary social knowledge that is based on an integrative reading of social communication systems. It allows us not only to identify the contents of the layman's everyday thinking in regard to important objects in life but also to understand the construction processes of this type of knowledge and its role in the activities and situations surrounding it.

Therefore, because of their important role in guiding behavior and social practices, representations are valuable tools for analyzing various social phenomena. In this regard, this theory is adopted in this study in an attempt to understand the relationship between society and mental illness in the current context of mental health, underpinned by the Psychiatric Reform.

Social representations can be understood as a specific type of knowledge whose purpose is the communication between individuals and the development of behaviors; they are symbolic sets that are both practical and dynamic (Moscovici, 2012). Jodelet (2005) describes social representations as practical knowledge directed at communication and understanding the social, material, and ideational context in which the human being lives. Thus, social representations are important tools that aid in understanding information and the positions and justifications of one's actions.

Coutinho and Costa (2015) note that to have access to the social representations of an object is to attempt to understand the ways in which people create, process, and interpret a phenomenon linked to their reality. In addition, social representations allow us to know the thoughts, feelings, perceptions, and life experiences shared by individuals within the context of the group to which they belong.

Social representations therefore play an important role in people' lives to the extent that they act as a guide in naming and defining the different aspects of everyday reality, in interpreting these aspects, and in a person's decision making and the position that he/she takes in response to the decisions made (Jodelet, 2001). Thus, the social representations made by different segments of society about the mentally ill person and the crazy person are valuable resources for understanding the practices developed and sustained in the mental health context.

\section{Method}

\section{Participants}

The study sample consisted of 150 participants: 50 secondary school students from public and private schools, with a mean age of 17 years $(S D=6.24)$, of both genders (male: $58 \%$ female: $42 \%$ ); 50 university students from psychology, medicine, and nursing programs in public and private institutions, mostly female $(82 \%)$, with a mean age of 24 years $(S D=5.98)$; and 50 mental health professionals, including psychiatrists, nurses, psychologists, social workers, and nursing technicians who worked in a CAPS (Centro de Atenção Psicossocial Psychosocial Care Center) and in a psychiatric hospital, mostly female (76\%), with a mean age of $42(S D=12.3)$. Thus, each social group accounted for $33.3 \%$ of the study sample. It should be added that the sample was selected using a non-probabilistic procedure, namely, 
convenience sampling. These three social groups were chosen due to the different proximities that they have to the field of mental health: secondary school students do not have a formal knowledge of the subject; university students have an academic contact with the subject; and health professionals have practical experience, in addition to the academic contact acquired during training. It is believed that these different proximities to the mental health context will provide a wider range of knowledge in regard to the phenomenon in contemporary society.

\section{Instruments}

The free word association technique (TALP) was used for data collection. This is a technique used in social representations research, in which the participants are asked to say the words or phrases that come immediately to mind when a prompt is presented by the researcher (Nóbrega $\&$ Coutinho, 2011). The TALP was used with the following prompts: "mentally ill person" and "crazy person". It should be noted that the prompts were presented to the participants in that exact order. Finally, the participants completed a sociodemographic questionnaire to characterize the sample (e.g., age, gender, and social group; the latter refers to the three groups that compose the sample: secondary school students, university students, and mental health professionals).

\section{Data Collection Procedure}

Initially, visits were made to the institutions, with the aim of presenting the research proposal and obtaining authorization for its implementation. After receiving authorization, the data collection process began. First, information was provided to the participants regarding the purpose of the study, the fact that there were no right or wrong answers, the right to choose to participate or not, and the guarantee of anonymity. For the secondary school students, data collection occurred in schools and in a collective manner. In the case of university students, data collection was performed in classrooms and in a collective manner. In the case of the mental health professionals, the data were collected on an individual basis in the institutions in which they worked. It should be noted that agreeing to participate in the study was indicated by signing an informed consent form and that in the case of secondary school students, assent forms were signed in addition to the informed consent form.

\section{Data Analysis Procedures}

The Tri-Deux-Mots software, version 2.2 (Cibois, 1995) was used to analyze the responses. This software includes a set of five computational subprograms, Impmot, Tabmot, Ecapem, Anecar, and Planfa, and includes correspondence factor analysis (CFA) among its data analysis methods. CFA is a technique that tests the relationships between opinion variables (responses to the prompts) and fixed variables (sociodemographic data) specific to individuals or groups. The responses to the prompts are called "contribution types", given that they are used in the construction of the factors that constitute the factorial structure. Thus, CFA is a technique that ascertains the connections between the characteristics of the individuals who comprise the group and their responses to a given prompt (Saraiva, Coutinho, \& Miranda, 2011). The sociodemographic data were tabulated and analyzed using the Statistical Package for Social Sciences (SPSS) for Windows, version 21.0, using frequency and percentage analysis (descriptive statistics).

\section{Ethical Procedures}

All ethical guidelines for research with human beings were complied with, according to Resolution 466/12 of the National Health Council, with the approval of the research ethics committee of the Federal University of Paraiba (UFP) Health Sciences Center, under Protocol no. $0543 / 2015$.

\section{Results and Discussion}

To understand the social representations of secondary school students, university health care students, and mental health professionals with regard to the objects of interest and to relate them to mental health care paradigms, the data from the TALP were processed in the Tri- 
Deux-Mots software. This software was used to graphically represent the proximity and distance between the fixed and opinion variables shown by the study participants. These variables were established from the socio-demographic questionnaire and the participants' responses to the prompts in the free association test.

The opinion variables corresponded to the participants' responses to the prompts "men- tally ill person" (prompt 1) and "crazy person" (prompt 2). The fixed variables included some participant characteristics from the socio-demographic questionnaire, such as social group, which referred to the three different groups comprising the study sample, i.e., secondary school students, university students, and mental health professionals.

Figure 1 shows the CFA plot for the social

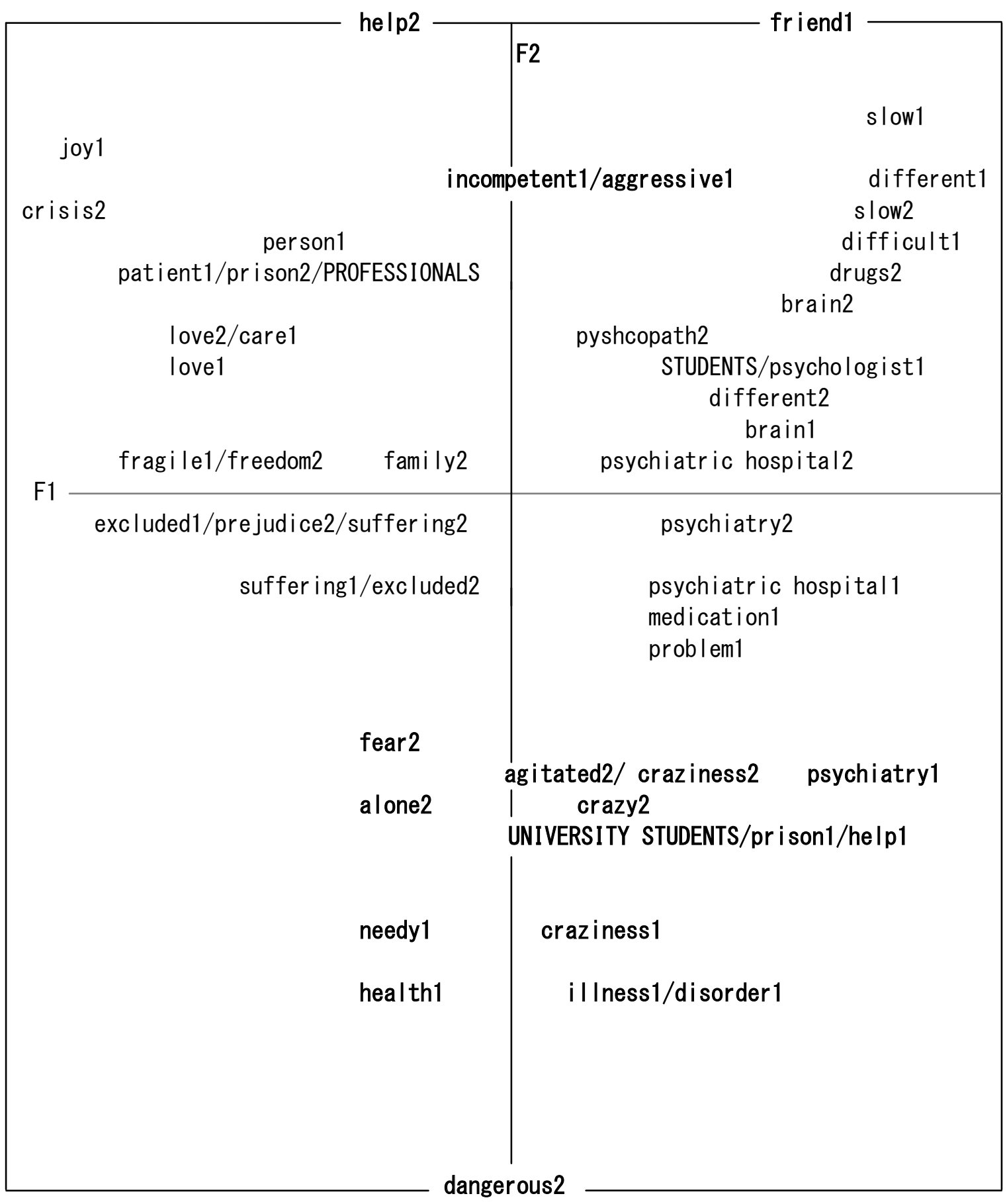

Figure 1. Correspondence factor analysis plot of representations of mentally ill (1) and crazy persons (2), produced by secondary school students, university students, and mental health professionals. 
representations made by the study participants, which was constructed from the response words, distributed antagonistically across the two factors (factors 1 and 2) of the chart. In terms of the participants' responses to the prompts, 1499 words were recorded. After the software combined semantically similar terms, 417 distinct terms were identified.

The first factor (F1), represented by the gray horizontal line, includes the representations with the most significant statistical value, explaining $67.8 \%$ of the total variance in responses. The second factor (F2), represented by the bold vertical line, represents $24.2 \%$ of total variance of the responses. The sum of the variances of the two factors totals $92 \%$, which is satisfactory for the interpretation of the results (Coutinho, Nóbrega, \& Araújo, 2011).

Note the contrast between the representations made by the secondary school students, university health care students, and mental health professionals in Figure 1. In factor 1 on the lefthand side of the plot, the mental health professionals' opinion variables can be observed. The mentally ill person (prompt 1) was represented by this group as a person. This word implies a perception of the person in psychic suffering as someone similar to "common" individuals, i.e., those not affected by mental disorders. This finding can be considered a breakthrough, given that in previous historical periods, these subjects were considered to be sub-human, with instincts closer to those of animals than those of humans (Foucault, 2012; Gil, 2010; Pessotti, 1994, 2001; Szasz, 1978). Research by Paes, Borba, Labronici, and Maftum (2010), concerning nurses' perceptions of the mentally ill, found data similar to this study, with nurses defining the mentally ill as human beings.

The mentally ill person was also objectified by the professionals as a patient, as someone fragile who needs love and attention and who faces suffering and exclusion. In general, this shows a social representation of the mentally ill anchored in the psychosocial paradigm, given that they are perceived as individuals and are not reduced solely to a disease. There is an under- standing of the suffering faced by these individuals, of the difficulties experienced in everyday life, marked by exclusion, resulting from the fact that these subjects are perceived very negatively by society (Maciel et al., 2011), and of their specific needs, including psychological and subjective needs. An example thereof are the terms love and care. Thus, one can identify in these professionals' responses an attitude of resistance to the still hegemonic biomedical paradigm, and the term "person" seems to be noted as though to affirm the equality of persons with mental disorders.

To the extent that the Psychiatric Reform is not only a network of services proposed to replace the mental asylum but that it also constitutes another care paradigm (Oliveira \& Caldana, 2016), this representation is in line with this proposal and favors the development of a new conception in mental health treatment/ care, which has the following characteristics: the fact that the object to be addressed is no longer simply the disease but now encompasses social, cultural, political, and economic factors as determinants of the disease process; the fact that working methods have migrated from predominantly administering drugs to the subject as a fundamental treatment agent, including his/her family and the community; the presence of a multidisciplinary team; and the fact that the intended result is no longer the cure - as symptom remission and submissive adaptation to the rules - and is now a care that respects and values the subjective aspects of human existence (Lancetti \& Amarante, 2006).

The phrase crazy person (prompt 2) was associated with the following terms: crisis, prison, suffering, prejudice, exclusion, love, help, family, and freedom. One can observe the presence of some negative elements in the representations of the crazy person, particularly prejudice and exclusion, as a result of a treatment based on seclusion due to constant crises. Also emerging for this prompt were responses that referred to a type of care in line with the psychosocial paradigm, characterized, for example, by the presence of help, love, family, and treatment in free- 
dom. Despite the crazy person being depicted as someone who has a greater lack of control due to constant crises, the professionals highlighted the importance of care characterized by social inclusion, as recommended by the Psychiatric Reform (Costa-Rosa, 2000).

In recent decades, mental health care in Brazil has undergone many changes. From the starting point of these changes, the Mental Health Workers Movement (Movimento dos Trabalhadores da Saúde Mental) in the 1970s, through the enactment of Law No. 10,216 in 2001 to its subsequent amendments, one can observe a significant range of actions aiming to change the reality of mental health care, promoting a process of deinstitutionalization through the creation and expansion of the care network. In this sense, the social representations of the mental health professionals observed in this study appear to be a reflection of this evolutionary context (Ribeiro, 2013).

Also in regard to factor 1 , on the right-hand side of the plot, the secondary school students' responses can be observed. This group objectified the mentally ill as different, slow, friend, incompetent, difficult, problem, someone who needs medication or a psychologist, and an individual who is in a psychiatric hospital and who must be kept away because he/she is aggressive and has brain issues. Conversely to the professionals, who viewed the mentally ill person as someone similar to so-called normal people, the secondary school students perceived them as someone unusual, different from other people, as highlighted by the term different. The mentally ill person was also perceived by these individuals as someone childlike, emphasizing the term leso (a word commonly used in the Northeast to refer to a mentally impaired person [translated here as "slow"]). Other responses characterized confining and medicalized practices, given that the subject was viewed as a threat and affected by an organically based disease located in the brain.

Thus, the representation of the mentally ill person was anchored in the biomedical paradigm, which has an organic view of problems and the effectiveness of drug treatment; there is little or no concern for the individuals or their loved ones. According to this paradigm, people in psychic suffering should be treated in psychiatric hospitals and kept away from society because they represent a threat to society (Costa-Rosa, 2000, 2012; Mondoni \& Costa Rosa, 2010).

The crazy person prompt was objectified by the secondary school students as slow, psychiatric hospital, psychiatrist, brain, different, psychopath, and drugs, and it was anchored in the biomedical paradigm. There was an association of the crazy person with greater fear and danger, as exemplified by the responses psychopath and drugs. Ochoa et al. (2011) note that society commonly associates craziness with drug use, indicating that drugs are a cause of mental disorders. This association generates even more prejudice, given that the crazy person is associated with another stigmatized group, drug users.

Regarding the relationship between craziness and danger, particularly the response $p s y$ chopath, Salles and Barros (2013) note that the picture of a troubled, psychotic killer is repeatedly conveyed in newspapers and films, suggesting an association between craziness and danger. This view has been widely publicized in society by the media and has thus become engrained in society. Despite being widespread in society, the perception that every person in psychic suffering is potentially dangerous is not corroborated by academic studies and appears to be the result of the more than 200 years of confinement and isolation of the crazy person by the medical system (Guarniero, Bellinghini, \& Gattaz, 2012; Salles \& Barros, 2013).

According to Salles and Barros (2013), intrinsic to the existence of psychiatric hospitals is the concept that every person in psychic suffering is dangerous. This concept, created based on the dominant ideology of the time, has been endorsed and disseminated in society and has become engrained. According to the ideology at the time, the role of psychiatric hospitals was not to treat the patient but rather to protect the healthy from the excesses and dangerousness of the crazy person. 
In factor 2, on the lower level of the plot, note the semantic field produced by university students in relation to the first prompt: mentally ill person. The mentally ill person was associated with disease, disorder, health, psychiatrist, needy, help, craziness, and prison. Among university students, one can identify a representation of the mentally ill anchored in the biomedical paradigm, which focuses on hospitalization and social exclusion. One can observe a similarity between the social representations of the mentally ill of secondary school students and of university students.

Regarding the biomedical paradigm and teaching in universities, Funghetto (2015) states that the education of health professionals is still marked by a biomedical, fragmented, and specialized model, which hinders a broader intervention in the population's health-disease process. One can observe this context reflected in training specific to the mental health field; Oliveira, Carvalho, Carvalho, and Silva (2013) note that in universities, mental health education is still focused on the traditional psychiatric model, with a focus that is not critical of reality. Professionals are trained in the context of the new services but using the old theoretical frameworks and methodologies. Therefore, it is clear that university education based on new mental health care concepts is something that is difficult to put into practice.

In terms of the crazy person prompt, it was associated with dangerous, fear, agitated, loneliness, craziness, and crazy, showing a representation anchored in the biomedical paradigm and associated with fear, similar to the crazy person social representation produced by the secondary school students, which views the crazy person as being uncontrolled and dangerous.

It can be observed that the representations of the mentally ill person and the crazy person are divergent between the three social groups. In general, the mentally ill person was viewed more positively by the professionals, secondary school students, and university students than the crazy person, with the students associating him/ her with fear.
The following responses were given for the term mentally ill person: fragile, needy, and help; in contrast, for the term crazy person, words such as the following were observed: $p s y$ chopath, fear, and drugs. Results similar to these were found by Maciel et al. (2011) in a study of mental health patients' families; these families represented the mentally ill person as son/ daughter and good, whereas the crazy person was represented as someone who causes fear. Therefore, according to Maciel (2007), the crazy person causes fear in the popular imagination and should therefore be excluded.

The results of this study indicate a closer relationship between the representations of secondary school and university students and a greater distance between the representations of professionals and these two other social groups. The secondary school and university students produced representations of the crazy person and the mentally ill person that were more anchored in the biomedical paradigm, whereas the professionals produced representations that were more anchored in the psychosocial paradigm. This result can be attributed to the fact that both secondary school and university students are not as close to the mental health field as health professionals. The reason is that the latter are immersed in this setting, experiencing more intensely the advances and setbacks in the field of mental health, they are in daily contact with the principles of the Reform, and they also have more interaction with people in psychic suffering.

Regarding coexistence with people in psychic suffering, Salles and Barros (2013) note that stigmatizing attitudes toward individuals with mental disorders may be associated with stereotypes that are endorsed when there is inadequate knowledge or when there is little contact with these subjects to correct them. Research indicates that the more contact and familiarity there is with people with mental disorders, the lower the prejudice tends to be (Angermeyer \& Matschinger, 2004; Arvaniti, Samakouri, Kalamara, Bochtsou, \& Livaditis, 2009; Corrigan, Edwards, Qreen, Thwart, \& Perm, 2001). 
The above studies support Alport's Intergroup Contact Hypothesis (1954/1979), which proposes that prejudice is strongly related to the interpersonal contact established between the minority group (in the specific case of this study, people in psychic suffering) and the majority group (people without mental disorders). According to this proposal, regular contact with members of another group can promote the reduction of stereotypes through contact with new information about the minority group.

Therefore, the different social contacts, experiences and proximities to the mental health field of these groups exert an influence on the construction of representations, which, in turn, guides their ways of thinking about the mental illness phenomenon and is reflected in the manner in which social relationships with people in psychic suffering are established (Jodelet, 2001; Moscovici, 2012).

\section{Final Considerations}

The results of this research demonstrate that in contemporary society, in which mental health care is guided by the Psychiatric Reform, there still prevails a representation of mental illness and the crazy person that is more anchored in the biomedical paradigm, reinforcing exclusion and social stigma.

The findings of this research also indicate that these representational objects, the mentally ill person and crazy person, have different connotations in the popular imagination, in that the social representation of the crazy person was more linked to danger and aggressiveness than that of the mentally ill person, who was viewed as a patient who needs care.

Given that social representations can be transformed by actions in the social context, it is important to conduct studies to assist society in reaching a more realistic and less stigmatized understanding of people in psychic suffering. Within this process, the important role of schools and universities should be noted, and it is essential that such institutions critically address issues surrounding mental health, emphasizing a more inclusive, realistic, and humanized view of people in psychic suffering.

For the social inclusion of people in psychic suffering to become effective, one must address the cultural heritage that established the concept that people with mental disorders should be feared and excluded. One must confront prejudice and create new possibilities for understanding mental illness, with continuous work being required throughout the community to assist it in understanding issues involving mental health.

It is hoped that this study brings to light reflections on the representations of mental disorders and provides data that will help in the implementation of the Psychiatric Reform at a national level. In particular, it is hoped that it will provide data that allow schools and universities to reflect on the training provided in terms of working and living in a context marked by the inclusion of people in psychic suffering. It is suggested that the issue of mental health be widely discussed, not only in these institutions but also in various social contexts. Note that to the extent that social representations are linked to social practices, the knowledge and analysis of such representations in the context of mental health represent a key step in the search for changes to this scenario toward a real inclusion of the person in psychic suffering.

A limitation of this study is the difference in data collection procedures between groups (collectively and individually); this difference may have generated some effect on the response pattern between groups. Additionally, the sample was selected in a non-probabilistic manner, which means that the results cannot be generalized. Nevertheless, the findings of this study are of great relevance in uncovering stereotypical and prejudice-reinforcing representations of mental illness.

It is important that other studies on this subject be performed, such as research that replicates this study in other regions or with other samples, in addition to broader studies that seek to identify elements in society that contribute to effectively implementing the Psychiatric Re- 
form and addressing prejudice against the person in psychic suffering.

\section{References}

Acioli Neto, M. L., \& Amarante, P. D. C. (2013). O Acompanhamento Terapêutico como Estratégia de Cuidado na Atenção Psicossocial. Psicologia Ciência e Profissão, 33(4), 964-975. Retrieved from http://www.scielo.br/pdf/pcp/v33n4/ v33n4a14.pdf

Alport, G. W. (1979). The nature of prejudice. New York: Addison-Wesley. (Original work published 1954)

Angermeyer, M. C., \& Matschinger, H. (2004). The Stereotype of Schizophrenia and its impact on discrimination against people with schizophrenia: Results from a representative survey in Germany. Schizophrenia Bulletin, 30(4), 10491061. Retrieved from https://www.ncbi.nlm.nih. gov/pubmed/15954207

Arvaniti, A., Samakouri, M., Kalamara, E., Bochtsou, V., \& Livaditis, C. B. M. (2009). Health service staff's attitudes towards patients with mental illness. Social Psychiatry and Psychiatric Epidemiology, 44(8), 658-665. doi: 10.1007/s00127008-0481-3

Camargo, B. V. (2015). Serge Moscovici(14/06/192516/11/2014): Um percussor inovador na psicologia social. Memorandum, 28, 240-245. Retrieved from http://www.europhd.eu/html/_onda02/07/ PDF/28th_lab_scientificmaterial/Camargo/camargo_2015_mosco.pdf

Cibois, U. F. R. (1995). Tri-deux-mots (Version 2.2) [Computer software]. Paris: Sciences Sociales.

Corrigan, P. W., Edwards, A. B., Qreen, A., Thwart, S. L., \& Perm, D. L. (2001). Prejudice, Social Distance, and Familiarity with Mental Illness. Schizophrenia Bulletin, 27(2), 219225. Retrieved from http://schizophreniabulletin.oxfordjournals.org/content/27/2/219. short?rss $=1$ \&ssource $=\mathrm{mfr}$

Corrigan, P., Markowitz, F., Watson, A., Rowan, D., \& Kubiak, M. (2003). An attribution model of public discrimination towards persons with mental illness. Journal of Health and Social Behavior, 44, 162-179. Retrieved from www. jstor.org/stable/1519806?seq=1\#page_scan tab contents
Costa, J., Jorge, M., Coutinho, M., Costa, E., \& Holanda, I. (2016). A reforma psiquiátrica e seus desdobramentos: Representações sociais dos profissionais e usuários da atenção psicossocial. Psicologia e Saber Social, 5(1), 35-45. doi: 10.12957/psi.saber.soc.2016.15855

Costa-Rosa, A. (2000). O modo psicossocial: Um paradigma das práticas substitutivas ao modo asilar. In P. D. C. Amarante (Ed.), Ensaios subjetividade, saúde mental, sociedade (pp. 141168). Rio de Janeiro, RJ: Editora da Fundação Oswaldo Cruz.

Costa-Rosa, A. (2012). A instituição de saúde mental como dispositivo social de produção de subjetividade. Estudo de Psicologia (Campinas), 29(1), 115-126. doi: 10.1590/ S0103-166X2012000100013

Coutinho, M. P. L., \& Costa, F. G. (2015). Depressão e insuficiência renal crônica: Uma análise psicossociológica. Psicologia \& Sociedade, 27(2), 448 449. doi: 10.1590/1807-03102015v27n2p449

Coutinho, M. P. L., Nóbrega, S. M., \& Araújo, L. S. (2011). Software Trideux- Uma ferramenta metodológica aplicada ao campo de pesquisa em representações sociais. In M. P. L. Coutinho \& E. R. A. Saraiva (Eds.), Métodos de pesquisa em Psicologia Social, perspectivas qualitativas e quantitativas (pp. 107-147). João Pessoa, PB: Editora Universitária.

Emerich, B. F., Campos, R. O., \& Passos, E. (2014). Direitos na loucura: $\mathrm{O}$ que dizem usuários e gestores dos Centros de Atenção Psicossocial (CAPS). Interface (Botucatu), 18(51), 685-696. doi: $10.1590 / 1807-57622013.1007$

Fonseca, T. M. G., \& Jaeger, R. L. (2012). A psiquiatrização da vida: Arranjos da loucura, hoje. Revista Polis e Psique, 2(3), 188-207. doi: http:// dx.doi.org/10.22456/2238-152X.40327

Foucault, M. (2012). História da loucura ( $9^{\text {th }}$ ed.). São Paulo, SP: Perspectiva.

Funghetto, S. S. (2015). A organização pedagógica nos cursos da área da saúde e seus reflexos no processo formativo - Uma análise a partir da avaliação (Doctoral dissertation, Universidade de Brasília, DF, Brazil).

Gil, I. M. A. (2010). Crenças e atitudes dos estudantes de Enfermagem acerca das doenças e doentes mentais: Impacto do Ensino Clínico de Enfermagem de Saúde Mental e Psiquiatria 
(Master thesis, Universidade de Coimbra, Portugal).

Goffman, E. (2008). Manicômios, prisões e conventos $\left(8^{\text {th }}\right.$ ed.). São Paulo, SP: Perspectiva.

Guarniero, F. B., Bellinghini, R. H., \& Gattaz, W. F. (2012). O estigma da esquizofrenia na mídia: Um levantamento de notícias publicadas em veículos brasileiros de grande circulação. Revista de Psiquiatria Clínica, 39(3), 80-84. doi: 10.1590/ S0101-60832012000300002

Jodelet, D. (2001). Representações sociais: Um domínio em expansão. In D. Jodelet (Ed.), As representações sociais (pp. 17-41). Rio de Janeiro, RJ: Editora da Universidade do Estado do Rio de Janeiro.

Jodelet, D. (2005). Representação social da loucura. Rio de Janeiro, RJ: Vozes.

Lancetti, A., \& Amarante, P. (2006). Saúde mental e saúde coletiva. In G. W. S. Campos, M. C. de S. Minayo, M. Akerman, M. D. Júnior, \& Y. M. de Carvalho (Eds.), Tratado de saúde coletiva (pp. 615-634). Rio de Janeiro, RJ: Fundação Oswaldo Cruz.

Maciel, S. C. (2007). Exclusão/inclusão social do doente mental/louco: Representações e práticas no contexto da reforma psiquiátrica (Doctoral dissertation, Universidade Federal da Paraíba, João Pessoa, PB, Brazil).

Maciel, S. C., Barros, D. R., Camino, L. F., \& Melo, J. R. F. (2011). Representações sociais de familiares acerca da loucura e do hospital psiquiátrico. Temas em Psicologia, 19(1), 193-204. Retrieved from http://pepsic.bvsalud.org

Maciel, S. C., Barros, D. R., Silva, A. O., \& Camino, L. (2009). Reforma psiquiátrica e inclusão social: Um estudo com familiares de doentes mentais. Psicologia: Ciência e Profissão, 29, 436447. doi: 10.1590/S1414-98932009000300002

Martins, A. K. L., Soares, F. D. S., Oliveira, F. B., \& Souza, A. M. A. (2011). Do ambiente manicomial aos serviços substitutivos: A evolução nas práticas em saúde mental. Revista SANARE, 10 (1), 28-34. Retrieved from https://sanare.emnuvens.com.br/sanare

Mondoni, D., \& Costa-Rosa, A. (2010). Reforma psiquiátrica e transição paradigmática no interior do estado de São Paulo. Psicologia: Teoria e Pesquisa 26(1), 39-47. doi: 10.1590/S010237722010000100006
Moscovici, S. (2012). Representações sociais: Investigações em psicologia social $\left(7^{\text {th }}\right.$ ed., P. A. Guareschi, Trans.). Petrópolis, RJ: Vozes.

Nóbrega, S. M., \& Coutinho, M. P. L. (2011). O Teste de Associação Livre de Palavras. In M. P. L. Coutinho \& E. R. A. Saraiva (Eds.), Métodos de pesquisa em Psicologia Social, perspectivas qualitativas e quantitativas (pp. 95-106). João Pessoa, PB: Editora Universitária.

Ochoa, S., Martínez, F., Ribas, M., García-Franco, M., López, E., Villellas, R., ...Haro, J. M. (2011). Estudio cualitativo sobre la autopercepción del estigma social en personas con esquizofrenia. Revista de la Asociación Española de Neuropsiquiatría, 31(111), 477-489. doi: 10.4321/S021157352011000300006

Oliveira, T. T. S. S., \& Caldana, R. H. L. (2016). Psicologia e práticas psicossociais: Narrativas e concepções de psicólogos de Centros de Atenção Psicossocial. Estudos Interdisciplinares em Psicologia, 7(2), 02-21. doi: 10.5433/2236-6407.2016v7n2p02

Oliveira, L. R. M., Carvalho, C. D., Carvalho, C. M. S., \& Silva, F. J. G. S., Jr. (2013). O ensino da saúde mental para enfermagem: Uma revisão da literatura. Revista Interdisciplinar, 6 (2), 152-159. Retrieved from https://revistainterdisciplinar.uninovafapi.edu.br/index.php/revinter/ article/view/60

Paes, M. R., Borba, L. O., Labronici, L. M., \& Maftum, M. A. (2010). Cuidado ao portador de transtorno mental: Percepção da equipe de enfermagem de um pronto atendimento. Ciência, Cuidado e Saúde, 9(2), 309-316. doi: 10.4025/ cienccuidsaude.v9i2.11238

Pessotti, I. (1994). A loucura e as épocas (2 ${ }^{\text {nd }}$ ed.). São Paulo, SP: Editora 34.

Pessotti, I. (2001). O século dos manicômios ( $2^{\text {nd }}$ ed.). São Paulo, SP: Editora 34.

Ribeiro, M. C. (2013). Os Centros de Atenção Psicossocial como espaços promotores de vida: Relatos da desinstitucionalização em Alagoas. Revista de Terapia Ocupacional, 24(3), 174-182. doi: 10.11606/issn.2238-6149.v24i3p174-82

Salles, M. M., \& Barros, S. (2013). Representações sociais de usuários de um Centro de Atenção Psicossocial e pessoas de sua rede sobre doença mental e inclusão social. Saúde e Sociedade, 22(4), 1059-1071. doi: 10.1590/S010412902013000400009 
Saraiva, E. R., Coutinho, M. P. L., \& Miranda, R. S. (2011). Software Trideux- Uma ferramenta metodológica aplicada ao campo de pesquisas em representações sociais. In M. P. L. Coutinho \& E. R. A. Saraiva (Eds.), Métodos de pesquisa em psicologia social: Perspectivas qualitativas e quantitativas (pp. 107-147). João Pessoa, PB: Editora Universitária.

Silva, F. S., Simpson, C. A., \& Dantas, R. C. (2014). Reforma psiquiátrica em Natal-RN: Evolução histórica e os desafios da assistência de enfermagem. Revista Eletrônica Saúde Mental Álcool e Drogas, 10(2), 101-109. doi: 10.11606/ issn.1806-6976.v10i2p101-109
Szasz, T. S. (1978). A Fabricação da Loucura: Um estudo comparativo entre a inquisição $e o$ movimento de saúde mental. Rio de Janeiro, RJ: Zahar.
Received: 07/12/2016

$1^{\text {st }}$ revision: $10 / 05 / 2017$

Accepted: 25/05/2017 